$<$ 原 著 $>$

Brain uptake index からみた肝不全ラットの血液脳関門における

\author{
トリプトファン輸送に関する研究 \\ 一とくに高アンモニア血症との関連を中心として一
}

中村 俊之 斎藤公志郎 森脇 久隆

橋本修武藤 泰敏*

要 旨：肝性脳症時の脳内中性丁ミノ酸 (NAA) 代謝異常の発現に, 血液脳関門 (BBB) がぞ のように関与するかを，門脈一下大静脈吻合 (PCA)，急性虚血性肝不全 (AIHF) およびアン $モ ニ ア ~\left(\mathrm{NH}_{3}\right)$ 負荷（経静脈的に $\mathrm{NH}_{3}$ を24h 投与）ラットにおいて, ${ }^{14} \mathrm{C}$-標識トリプトファン ( ${ }^{14} \mathrm{C}$-Trp) の brain uptake index（BUI）指標として検討した。 その結果, PCA, AIHF と むに ${ }^{14} \mathrm{C}$-Trp BUI は対照群に比し有意に高く, BBBに和ける Trpの透過性元進が, 脳内 NAA 代謝異常の発現に重要な役割を果たすと考鼻られた。 さらに, $\mathrm{NH}_{3}$ 負荷ラットにおいてす ${ }^{14} \mathrm{C}$ Trpおよび14C-イソロイシンの BUI は対照群に比し有意に高く，このBBBにおける透過性亢 進と高 $\mathrm{NH}_{3}$ 血症との間に密接な関連が示唆された. な报, $\mathrm{NH}_{3}$ 解毒のため増加した脳内グルタ ミン濃度と ${ }^{14} \mathrm{C}-T r p$ BUI が有意の正相関を示したことから，この透過性の亢進が脳内グルタミ ン濃度の上昇によって若起される可能性も強く示唆された。

索引用語：肝性脳症血液脳関門 高フンモニフ血症 脳内中性フミノ酸濃度 Brain uptake index

\section{緒 言}

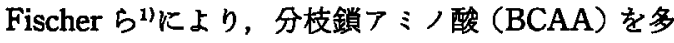
く含んだ特殊組成了ミノ酸輸液が肝性脳症に対して速 好的覚醒効果を有することが報告されて以来, 肝性脳 症とフミノ酸代謝異常あるいは脳内もノフミン代謝異 常との関連がしだいに明らかにされてきた。 また動物 を用いた肝不全モデルです芳香族アミノ酸 (AAA)で あるフェニルフラニン (Phe), チロシン (Tyr) およ びトリプトファン ( Trp)の血中および脳内における増 加を特徵とするフミノ酸代謝異常 ${ }^{21}$ と，それに起因す ると考えられる脳内ノルエピネフリン(NE)の減少"), セロトニン (5-HT) の増加出が報告されている.

一方, 周知のごとく，血液と譄との間には血液脳関 門(BBB)が介在しており，AAA の血中濃度と脳内濃 度を比較した場合, 特に門脈一下大静脈吻合ラット (PCA) においては, 競合てミノ酸である BCAA の減 少を考虑しても，血中濃度の変化のみで脳内での

- 岐皋大学第 1 内科

$<$ 受付日63年 8 月22日 $>$
AAA の增加を説明するに困難がある゙ことなどから， 肝不全時の BBBに拈けるアミノ酸の透過性について も研究が進められてきた。 その結果，一般に訮不全時 には中性アミ，酸 (NAA)のBBBに括ける透過性が 六進することが明らがされてきたが、占)，この透過性 光進の機序についてはいまだ充分に解明されたとは言 い難い.

この点に関して James ら゙は, BBBにおける NAA の透過性穴進が，脳内でフンモニア $\left(\mathrm{NH}_{3}\right)$ 解毒のた め增加したグルタミン (Gln).と NAA との exchange transport の元進によって使起される可能性を指摘し 注目される。しかし，敩密に慢性および急性，さらに $\mathrm{NH}_{3}$ 負荷による高 $\mathrm{NH}_{3}$ 血症モデルを対比検討した報 告はいまたみられない。

そこで我々は, AAA の 1 つで5-HT の前駆物質であ り，肝性脳症と密接な関連が示唆されている(4,5,8)Trp に着目し，そのBBBにおける脳内移行が肝不全時に どように変化するかを，慢性括上び急性，2つの肝 不全モデルを用いて比較検討した。さらに，正常ラッ トに $\mathrm{NH}_{3}$ を経静脈的に持続投与したさい蔆起される 
高 $\mathrm{NH}_{3}$ 血症との関連についてす検討を加えた。

$$
\text { 方法 }
$$

1. 肝不全モテル

ウィスター系雄性ラット（200－300g）を用い，以下 のモデルを作製した。

a) 門脈一下大静脈吻合ラット（PCA）

エーテル麻醉下，小畠2)の方法に準じて作製し，4週 間後実験に供した。な拉，開腹術のみ行ったものを対 照群（Sham）とした。

b）急性虚血徃肝不全ラット（AIHF）

PCA 作製48時間後に, エーテル麻醉下再開腹し, 肝 動脈を結愁離断の上, 血流遮断 8 時間後に実験に供し た， 2 度の開腹術のみを行ったるのを対照群（Sham） とし, 両群とも 2 度目の開腹術直後抢よび以後 2 時間 毎に, $10 \%$ ブドゥ糖液 $16 \mathrm{~m} l / \mathrm{kg}$ を腹腔内投与した。な 技，血流遮断 8 時間後の血糖は Sham $223 \pm 10 \mathrm{mg} / \mathrm{d} l$ $(n=3)$, AIHF 108 $\pm 40(n=5)$ であった.

c) $\mathrm{NH}_{3}$ 負荷ラット $\left(\mathrm{NH}_{3}-\mathrm{R}\right)$

林9の方法に準じ，エーテル麻醉下ラット頚静脈よ りシリコンチューブを㨂入し，無拘束の状態で代謝 ケージに入れ，24時間完全静脈栄養下， $\mathrm{NH}_{3}$ を持続投 与した。輸液の組成 ${ }^{9}$ は, 市販了ミノ酸混液(Ispol，大 五栄盖化学, 大阪)最終総フミノ酸濃度として1.67\%, グルコース $15.0 \%, \mathrm{Na} 48.5$ (mEq/ $l$, 以下同じ), K 4.2, $\mathrm{Cl} 48.5, \mathrm{Mg} 2.5, \mathrm{Ca} 3.0$, 乳酸21.0で, さらに ビタミン $\mathrm{B}_{1}, \mathrm{~B}_{2}, \mathrm{~B}_{6}$ および $\mathrm{B}_{12}$ を加市た. $\mathrm{NH}_{3}-\mathrm{R} に は ，$ 上記混液に酶酸アンモ 京都) $50 \mathrm{mM}, 100 \mathrm{mM}$ 执よび $200 \mathrm{mM}$ となるように 加え， 3 群を作製した，50怙よび100mM 群には酢酸ナ トリウム ( NaAc，半井)をそれぞれ150および100 加党，酶酸イオンの最終濃度は同一 $(200 \mathrm{mM})$ になる 上うにした。なお， NaAc 200mM を加克たものを対照 群とした。輸液には Manostat 社製 Cassete Pumpを 用い, 輸液速度は約 $3.3 \mathrm{~m} l / \mathrm{hr}$ とした。

\section{Brain uptake index (BUI)}

Oldendorf ${ }^{10)} の$ single injection method 考用い, 次 式より BUI を求めた。

\section{$\frac{\text { 脳組織 }{ }^{14} \mathrm{C} / \text { 脳組織到 } \mathrm{H}}{\text { Inject. }{ }^{14} \mathrm{C} / \text { Inject. }{ }^{3} \mathrm{H}} \times 100(\%)$}

ナなわち, pentobarbital (40mg/kg，腹腔内投与) にて麻酔後, ${ }^{14} \mathrm{C}$-標識 $\operatorname{Trp}\left({ }^{14} \mathrm{C}-\mathrm{Trp}\right)$ 混液 $0.2 \mathrm{~m} l$ を27 $\mathrm{G}$ の注射針を用い総䅡動脈より bolus injection L， 15 秒後に断頭，同側の頭頂葉から側頍葉にかけての皮質 約100mgを試料として採取した。試料を Soluene
350 (Packard Instr. USA) $\operatorname{lm} l$ 中に入れ，一昼夜室 温にて静置融解させた後，Dimilume 30 (Packard) 10 $\mathrm{m} l$ を加克, 液体シンチレーションカウンター（Beckmann LS7500）にて， ${ }^{14} \mathrm{C}$ 打よび $\mathrm{H}$ の放射活性を分別 測定した. なお, injected solution(inj. sol.)は, $10 \mathrm{mM}$ の $\mathrm{N}$-2-hydroxyethylpiperazine- $\mathrm{N}^{\prime}$-2-ethanesulfonic acid を含む pH 7.4の Ringer 液に, ${ }^{14} \mathrm{C}$-Trp あるいは ${ }^{14} \mathrm{C}$-標識イソロイシン $\left({ }^{14} \mathrm{C}\right.$-Ile) をそれそれ最終濃度 $1.25 \mu \mathrm{Ci} / \mathrm{m} l$ および3 $\mathrm{H} \cdot \mathrm{H}_{2} \mathrm{O}$ を同じく $5 \mu \mathrm{Ci} / \mathrm{m} l$ となる よらに加え作製した。

なお， ${ }^{14} \mathrm{C}$-Trp の BUI に対する $\mathrm{NH}_{3}$ の直接の影響 は, inj. sol. に最終濃度で $0.713 \mathrm{mM}$ となるように $\mathrm{NH}_{4} \mathrm{Ac}$ を加えて, 同様に検討し, $\mathrm{NaAc}$ を同濃度加え たるのを対照群とした。

さらに kinetic study に際しては inj. sol. に非標識 $\operatorname{Trp}$ (日本理化学薬品，東京）を最終濃度で21.6 $\mu \mathrm{M}$ 〜2.02mM となるょうに加克，同様に ${ }^{14} \mathrm{C}-\mathrm{Trp} の$ BUI を求めた上, 脳血流量を $1 \mathrm{~m} l / \mathrm{min} / \mathrm{g}^{11)}$ とて total influx（T.I.）を計算した。後述のごとく, T.I. は, saturable (sat.) および nonsaturable (nonsat.) の 2 つの成分から成り，後者の kineticsについては0.27 $\mathrm{mM} \sim 2.02 \mathrm{mM}$ における直線の傾きから $\mathrm{Kd}$ 求め た. Sat. influxは T.I. ๖り nonsat. influx を差し引い て求め6,12), さらに Lineweaver-Burke plots より $\mathrm{Km}$ およびVmax を計算した。

\section{3. 標識化合物}

L- (methylene $\left.{ }^{-14} \mathrm{C}\right)-\operatorname{Trp}(58 \mathrm{mCi} / \mathrm{mmol}), \mathrm{L}-(\mathrm{U}$ $\left.{ }^{14} \mathrm{C}\right)$-Ile $(330 \mathrm{mCi} / \mathrm{mmol})$ 扰よひ ${ }^{* 3} \mathrm{H}-\mathrm{H}_{2} \mathrm{O}(5 \mathrm{mCi} / \mathrm{ml})$ は Amersham Japan 上り塐入した。

\section{4. 血掑遊離 NAA 湌度}

$5 \%$ スルフォサリチル酸で除蛋白後, 日立835型了ミ ノ酸自動分析機にて測定した. Albumin-unbound Trp （以下遊離 Trp）は Amicon MPS-I にて ultra filtrate 後, 同様に測定した ${ }^{19)}$.

\section{5. 脳内 NAA 湿度}

半脳を $10 \%$ リクロル酢酸にてホモゲナイズ後，遠 心分離し，上清をエーテルと混和，エーテル不容画分 のみ採取し,エパポレーターにて蒸発乾固後, 0.1M ク

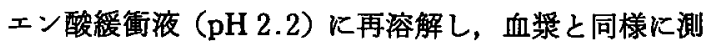
定した.

\section{Trp の推定脳内進入速度（Vpre）}

2 の結果に基づき次式より求めた ${ }^{14)}$.なお，他の競合 フミノ酸の $\mathrm{Km}$ 值は Pardridge ${ }^{14}$ により実測されたす のを用いた。 


$$
\begin{aligned}
& \text { Vpre }=V \max \times[S] / K m(a p p)+[S] \\
& +K d \times[S] \\
& K m(a p p)=K m\left(1+\Sigma[S]^{\prime} / K^{\prime} m^{\prime}\right)
\end{aligned}
$$

\section{7. 脳内 Gln 湌度}

Lund ${ }^{15}$ および Bernt \& Bergmeyer ${ }^{16)} の$ 万法に準じ て测定した。半脳のホモゲネートをすみゃかに1M $\mathrm{HClO}_{4}$ Kて除蛋白後遠心分離し，上清を 2 つに分け た。一方は $\mathrm{K}_{3} \mathrm{PO}_{4}$ にて $\mathrm{pH}$ 9に調整し，さらに遠心分離 し，上清をダルタミン酸 (Glu) 測定用とした。 また他 方は $30 \% \mathrm{KOH}$ にて中性化後遠心分離し，上清を $\mathrm{Gln}$ 測定用とした。まず，前者を用いて，ADP(Grade IX, Sigma Chemical CO., USA) および $\beta$-NAD (Grade III, Sigma) の存在下, L-Glutamic dehydrogenase (Type II, Sigma) 添加前後の吸光度 $(340 \mathrm{~nm})$ の差 上り Glu 湢度を求め，一方，Gln は，L-Glutaminase （Grade V, Sigma）にて Glu に変換後同様に測定し, Glu 濃度との差から求めた。

\section{8. 血中 $\mathrm{NH}_{3}$ 湌度}

醭素法 (デタミナー $\mathrm{NH}_{3}$, 協和発醳) にて測定した。

\section{9. 統計学的方法}

平均値の美の検定には t-test を用い，2 群間の比較 は Student $の$ criteria に， 3 群間以上の比較に際して は Bonferroni ${ }^{17)}$ の criteria に従った。をた，2つの関 連した変数間の相関は linear regression analysis を 用いて分析し，有意性の検定には t-test を用いた。
結果

1. PCA、AIHFにおける血浆および聯内 NAA 濃 度

PCA(Table 1)の血では，対照群に比しスレオニ ソ (Thr), パリン (Val), ロイシン (Leu), Ile が有 意に減少し，Tyr およびPheはそれぞれ対照群の1.6 および1.3倍と有意に增加していた，Trp 濃度には差 はみられなかった。脳内です Tyr(2.2倍), $\mathrm{Phe}(2.1)$, ヒスチシン (His, 1.7)，メチオニン (Met, 1.8) お よびTrp (2.5) が有意に增加していた。一方, AIHF (Table 2) の血浆では対照群に比しHisを除く BCAA を含めたすべての NAA が著増 (1.8〜13.5倍) し, 脳内でも Ile を除くすべての NAA が有意に増加 （1.3６.7倍）していた。

\section{2. 正常ラット BBBに书ける Trp 輸送の kinetics}

TrpのT.I.は nonsat. (line b) および sat. (line c) の 2 つから成ることが示された(Fig. 1(A)). Nonsat.

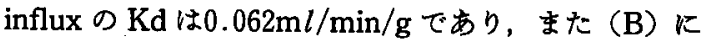
示した Lineweaver-Burke plotsより求めた sat. influxの $\mathrm{Km}$ およびVmaxはそれぞれ0.136mM お

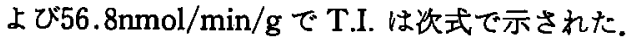

Total influx $(\mathrm{nmol} / \mathrm{min} . / \mathrm{g})=56.8 \times[\mathrm{S}] / 0.136+$ [S] $+0.062 \times[\mathrm{S}]$

\section{PCA およひ AIHFにおける遊離 Trpの Vpre}

PCA (Table 1) においては Sham の1.157 \pm 0.392

Table 1 Plasma and brain amino acid concentrations and predicted

\begin{tabular}{|c|c|c|c|c|}
\hline \multirow{2}{*}{$\begin{array}{l}\text { Amino } \\
\text { Acids }\end{array}$} & \multicolumn{2}{|c|}{ Plasma $(\mu \mathrm{mol} / \mathrm{m} l)$} & \multicolumn{2}{|c|}{$\operatorname{Brain}(\mu \mathrm{mol} / \mathrm{g})$} \\
\hline & $\operatorname{Sham}(n=12)$ & $\operatorname{PCA}(n=9)$ & $\operatorname{Sham}(n=12)$ & $\operatorname{PCA}(n=9)$ \\
\hline Thr & $0.170 \pm 0.029$ & $0.122 \pm 0.020^{* * *}$ & $0.486 \pm 0.049$ & $0.588 \pm 0.147$ \\
\hline Val & $0.204 \pm 0.023$ & $0.161 \pm 0.040^{*}$ & $0.104 \pm 0.013$ & $0.118 \pm 0.047$ \\
\hline Met & $0.043 \pm 0.009$ & $0.048 \pm 0.010$ & $0.025 \pm 0.011$ & $0.046 \pm 0.016^{* *}$ \\
\hline Ile & $0.096 \pm 0.011$ & $0.074 \pm 0.017^{* *}$ & $0.057 \pm 0.009$ & $0.068 \pm 0.032$ \\
\hline Leu & $0.159 \pm 0.018$ & $0.124 \pm 0.032$ & $0.101 \pm 0.014$ & $0.125 \pm 0.047$ \\
\hline Tyr & $0.053 \pm 0.019$ & $0.084 \pm 0.022^{* *}$ & $0.074 \pm 0.052$ & $0.163 \pm 0.056^{* *}$ \\
\hline Phe & $0.061 \pm 0.004$ & $0.082 \pm 0.015^{* *}$ & $0.062 \pm 0.022$ & $0.131 \pm 0.041^{* * *}$ \\
\hline His & $0.065 \pm 0.009$ & $0.077 \pm 0.019$ & $0.077 \pm 0.028$ & $0.132 \pm 0.042^{* *}$ \\
\hline T. Trpa & $0.081 \pm 0.021$ & $0.083 \pm 0.019$ & - & - \\
\hline F. $\operatorname{Trp}^{\mathrm{b}}$ & $\begin{array}{c}0.012 \pm 0.004 \\
(n=10)\end{array}$ & $\begin{array}{c}0.011 \pm 0.003 \\
(n=8)\end{array}$ & $\begin{array}{c}0.010 \pm 0.003 \\
(\mathrm{n}=6)\end{array}$ & $\begin{array}{c}0.025 \pm 0.006 * \cdots \\
(n=6)\end{array}$ \\
\hline \multicolumn{2}{|c|}{ Vpre of free Trp influx } & $(\mathrm{nmol} / \mathrm{min} . \mathrm{g})$ & $1.157 \pm 0.392$ & $1.100 \pm 0.330$ \\
\hline
\end{tabular}
velocity (Vpre) of free tryptophan influx into brain in rats with portacaval anastomosis (PCA). 

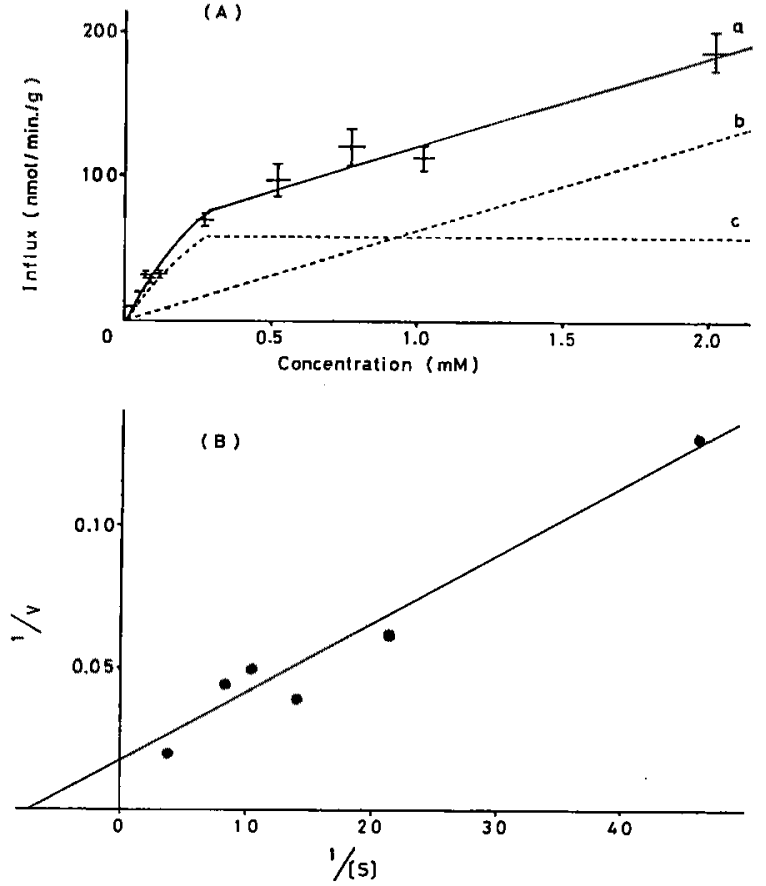

Fig. 1 (A) Brain tryptophan influx curve in normal rats. Each point of line a indicates the mean of at least five different experiments with the $\mathrm{S}$. E. given by the vertical bar. Line $c$ represents the saturable component obtained by subtracting apparent nonsaturable component (line b) from the total influx curve (line a). (B) LineweaverBurke plots of the saturable component of tryptophan influx

$\mathrm{nmol} / \mathrm{min} / \mathrm{g}$ に対し， $1.100 \pm 0.330$ と有意の美は認め なかった. 一方, AIHF (Table 2) では Sham の $0.791 \pm 0.134$ に対し，1.136士0.355と有意に增加して いた.

\section{PCA おょひ AIHFにおける にC-Trpの BUI}

Fig. 2 に示すごとく, PCA での ${ }^{14} \mathrm{C}-T r p の$ BUI $47.1 \pm 8.0 \%$ と対照群の33.8土6.8に比し, $139.3 \%$ と有 意な増加を示した. AIHFについても同様に45.6土 $5.4 \%$ と対照群の $24.8 \pm 6.0$ に比し $183.9 \%$ と有意な増 加を示した。

5. PCA, AIHFにおける血中 $\mathrm{NH}_{3}$ 湶度およひ脳内 Gln 湌度 (Fig. 3)

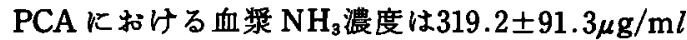
と対照群の74.4

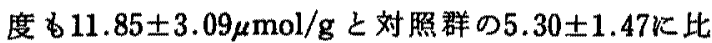
し有意に増加していた。AIHFです同様に血浆 $\mathrm{NH}_{3}$ 濃

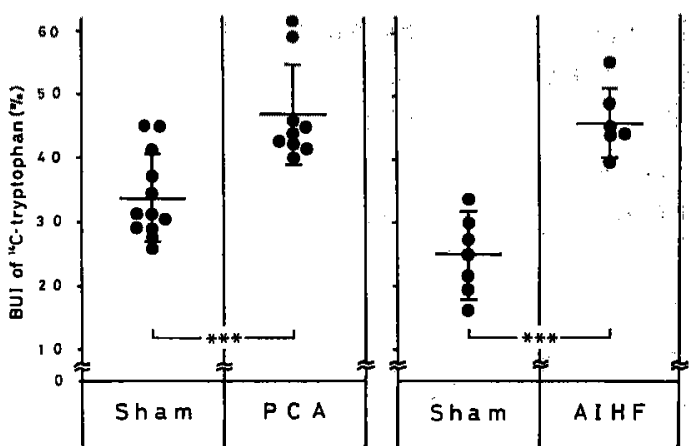

Fig. 2 Brain uptake index (BUI) of ${ }^{14} \mathrm{C}$-labeled tryptophan in rats with portacaval anastomosis (PCA) and acute ischemic hepatic failure (AIHF). ${ }^{* * *}: p<0.001$

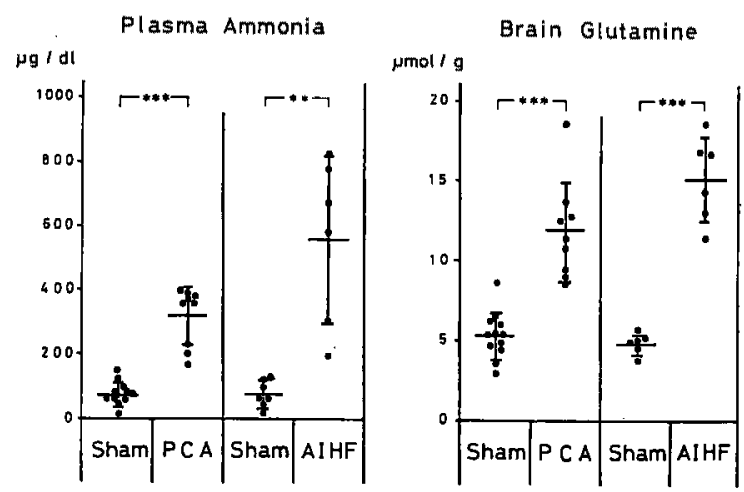

Fig. 3 Plasma ammonia and brain gulutamine concentrations in rats with portacaval anastomosis (PCA) and acute ischemic hepatic failure (AIHF). **; p<0.01, ***: $: 00.001$

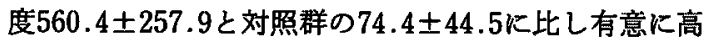

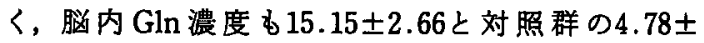
0.62に比し, 有意に増加していた。

6. PCA おょびAIHFにおける脳内 $\operatorname{Gln}$ 沙度と ${ }^{14} \mathrm{C}$-Trp BUI $の$ 関係

Fig. 4 は, PCA, AIHF および各々の対照群の脳内 Gln 濃度と ${ }^{4}$ C-Trp BUI の関係を示したものである が，有意の正相関がみられた。

7. $\mathrm{NH}_{3}-\mathrm{R}$ における ${ }^{14} \mathrm{C}$-Trp および14 C-Ile の BUI ${ }^{14}$ C-Trp の BUI (Fig. 5) は，対照群の45.5土4.5\%

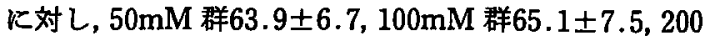
$\mathrm{mM}$ 群69.7士11.0といずれす有意な増加を示した。し かし，負荷濃度による有意な差異は諗められなかった。

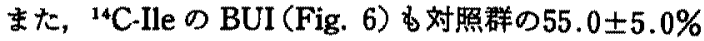


Table 2 Plasma and brain amino acid concentrations and predicted velocity (Vpre) of free tryptophan influx into brain in rats with acute ischemic hepatic failure (AIHF).

\begin{tabular}{|c|c|c|c|c|}
\hline \multirow{2}{*}{$\begin{array}{l}\text { Amino } \\
\text { Acids }\end{array}$} & \multicolumn{2}{|c|}{$\operatorname{Plasma}(\mu \mathrm{mol} / \mathrm{m} l)$} & \multicolumn{2}{|c|}{$\operatorname{Brain}(\mu \mathrm{mol} / \mathrm{g})$} \\
\hline & $\operatorname{Sham}(n=7)$ & $\operatorname{AIHF}(n=6)$ & $\operatorname{Sham}(n=7)$ & $\operatorname{AIHF}(n=6)$ \\
\hline Thr & $0.156 \pm 0.026$ & $0.639 \pm 0.174^{* *}$ & $0.534 \pm 0.042$ & $0.771 \pm 0.089^{* * *}$ \\
\hline Val & $0.172 \pm 0.027$ & $0.324 \pm 0.066$ & $0.089 \pm 0.008$ & $0.119 \pm 0.023^{*}$ \\
\hline Met & $0.036 \pm 0.008$ & $0.303 \pm 0.096^{* *}$ & $0.029 \pm 0.004$ & $0.101 \pm 0.022^{* * *}$ \\
\hline lle & $0.076 \pm 0.011$ & $0.140 \pm 0.036^{* *}$ & $0.046 \pm 0.004$ & $0.049 \pm 0.008$ \\
\hline Leu & $0.130 \pm 0.019$ & $0.269 \pm 0.066^{* *}$ & $0.087 \pm 0.007$ & $0.114 \pm 0.021^{*}$ \\
\hline Tyr & $0.040 \pm 0.005$ & $0.540 \pm 0.137 * \cdots$ & $0.052 \pm 0.004$ & $0.350 \pm 0.053^{* * *}$ \\
\hline Phe & $0.072 \pm 0.008$ & $0.444 \pm 0.113^{* * *}$ & $0.078 \pm 0.004$ & $0.251 \pm 0.046^{* * *}$ \\
\hline His & $0.077 \pm 0.007$ & $0.099 \pm 0.050$ & $0.081 \pm 0.009$ & $0.190 \pm 0.033^{* * *}$ \\
\hline T. $\operatorname{Trp}^{\mathrm{a}}$ & $0.080 \pm 0.011$ & $0.119 \pm 0.034^{*}$ & - & - \\
\hline F. $\operatorname{Trp}^{\mathrm{b}}$ & $0.007 \pm 0.001$ & $0.036 \pm 0.007^{* * *}$ & $0.012 \pm 0.001$ & $0.025 \pm 0.006^{* *}$ \\
\hline \multicolumn{2}{|c|}{ Vpre of free Trp influx } & $(\mathrm{nmol} / \mathrm{min} / \mathrm{g})$ & $0.791 \pm 0.134$ & $1.136 \pm 0.355^{*}$ \\
\hline
\end{tabular}

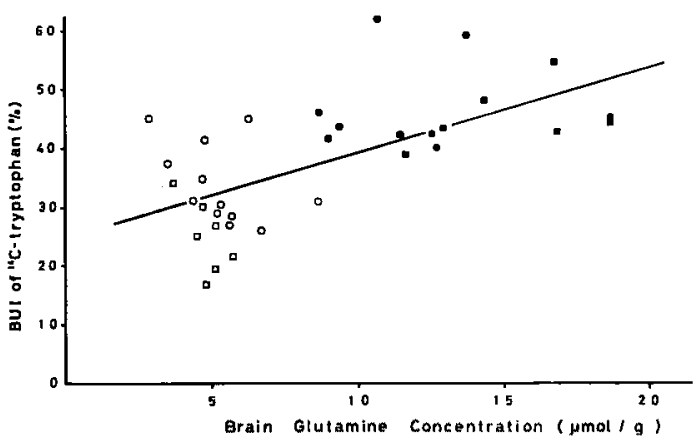

Fig. 4 Significant positive correlation between brain gulutamine concentration and brain uptake index (BUI) of ${ }^{14} \mathrm{C}$-labeled tryptophan in rats with portacaval anastomosis (PCA) and acute ischemic hepatic failure (AIHF) $y=1.5 x+24.8$, $\mathrm{r}=0.634, \mathrm{p}<0.001$

$O$; sham for PCA, $\square$; sham for AIHF, $\bigcirc$ PCA, : AIHF

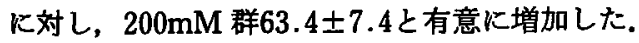

8. ${ }^{14} \mathrm{C}$-Trp BUI に対する $\mathrm{NH}_{3}$ の直接の影䈏（Fig. 7)

対照群の40.1土3.0\%に対 し， $\mathrm{NH}_{3}$ 同時注入群 $38.9 \pm 2.6$ 差異はみられなかった。

9. $\mathbf{N H}_{3}-\mathbf{R}$ における脳内 NAA お゙よひ Gln 源度

$50 \mathrm{mM}$ 群では, Phe, Hisが, 100mM 群怙よび200 mM 群では Thr, Met, Tyr, Phe, His が対照群に比

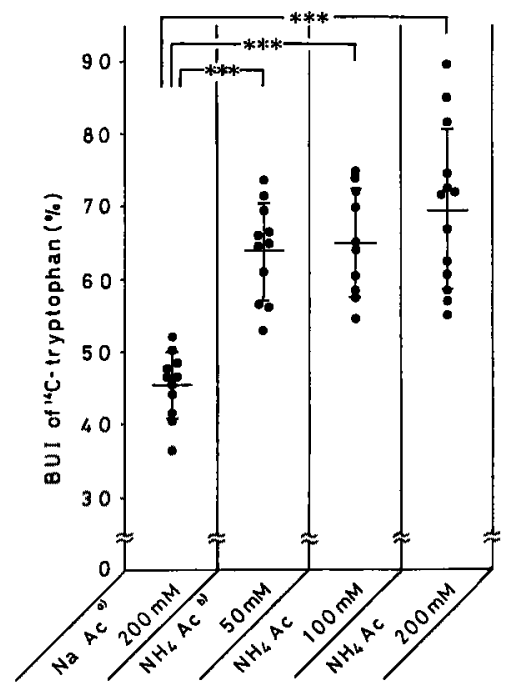

Fig. 5 Brain uptake index (BUI) of ${ }^{14} \mathrm{C}$-labeled tryptophan in rats, in which varying concentration of ammonium acetate was continuosly infused for 24 hrs. a); sodium acetate, b) ; ammonium acetate, ${ }^{* * *} ; p<0.001$

し有意に増加していた。一方, BCAA には有意の変化 はみられなかった（Table 3).

また，脳内 $G \ln$ 濃度は，対照群の $4.67 \pm 0.58 \mu \mathrm{mol} / \mathrm{g}$

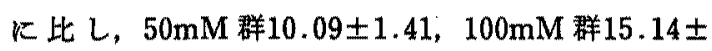
2.36, $200 \mathrm{mM}$ 群19.25士1.98といずれも有意に高く, 


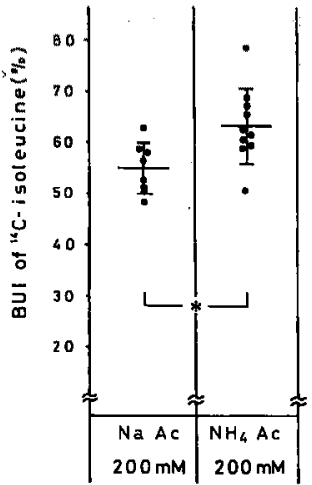

Fig. 6 Brain uktake index (BUI) of ${ }^{14} \mathrm{C}$-labeled isoleucine in rats, in which varying concentration of ammonium acetate was continuously infused for $24 \mathrm{hrs}$. $\mathrm{NaAc}$; sodium acetate, $\mathrm{NH}_{4} \mathrm{Ac}$ : ammonium acetate, ${ }^{*} ; p<0.05$

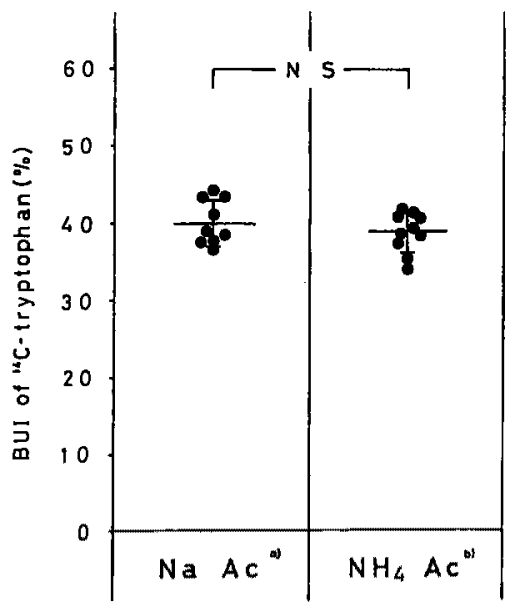

Fig. 7 Effect of ammonium acetate added in injection solution on brain uptake index (BUI) of ${ }^{14} \mathrm{C}$-labeled tryptophan in normal rats. a); sodium acetate, b) ; ammonium acetate, NS ; not significant

\section{さらに50から $200 \mathrm{mM}$ まで負荷量が増えるに従い有意} の増加を示した。

10. $\mathrm{NH}_{3}-\mathrm{R}$ における脳内 Gln 濼度と脳内 AAA 混 度书よU゙14C-Trp BUI との関俰

Fig. 8 に示すごとく脳内 $\mathrm{G} \ln$ 濃度と脳内 AAA 濃 度の和 (Tyr +Phe+Trp) との間に有意の正の相関が 認められた。 また，Fig. 9 に示すごとく脳内 Gln 濃度 と ${ }^{14} \mathrm{C}$-Trpの BUI との間にも有意の正の相関が認め

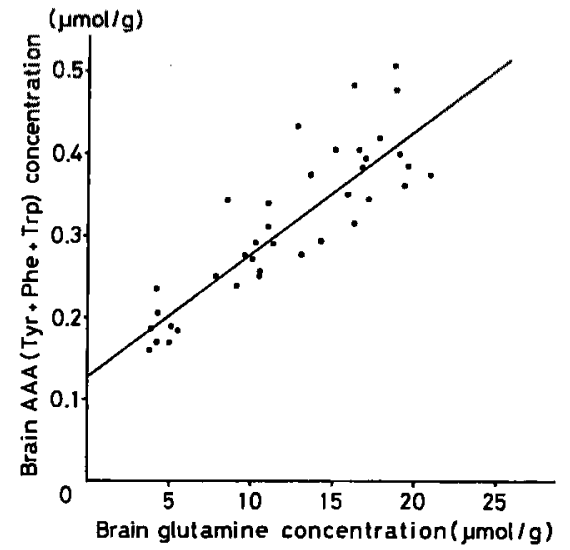

Fig. 8 Significant positive correlation between brain glutamine concentration and brain aromatic amino acid (tyrosine+phenylalanine+ tryptophan) concentration in ammonium acetate administered rats. $\mathrm{y}=0.014 \mathrm{x}+0.128, \mathrm{r}=0.864$, $\mathrm{p}<0.001$

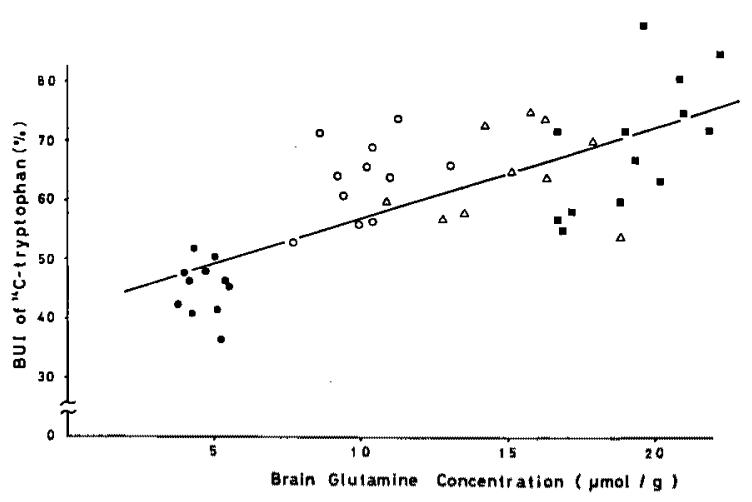

Fig. 9 Significant positive correlation between brain glutamine concentration and brain uptake index (BUI) of ${ }^{14} \mathrm{C}$-labeled tryptophan in ammonium acetate administered rats. $y=1.6 x+41.7$, $\mathrm{r}=0.750, \mathrm{p}<0.001$

; sodium acetate $200 \mathrm{mM}, O$; sodium acetate $150 \mathrm{mM}+$ ammonium acetate $50 \mathrm{mM}, \triangle$; sodium acetate $100 \mathrm{mM}+$ ammonium acetate $100 \mathrm{mM}, \mathbf{a}$; ammonium acetate $200 \mathrm{mM}$. Each solution was continuously infused for $24 \mathrm{hrs}$ at a flow speed of $3.3 \mathrm{ml} / \mathrm{hr}$.

られた。

$$
\text { 考察 }
$$

肝不全時には AAA の増加と BCAA の減少,すなわ ち Fischer 比(Val+Leu+Ile/Tyr + Phe モル比)の低 
Table 3 Brain amino acid concentrations in ammonium acetate administered rats.

\begin{tabular}{|c|c|c|c|c|c|c|c|c|c|c|}
\hline \multirow{2}{*}{$\underset{\text { Acids }}{\text { Amino }}$} & \multirow{2}{*}{$\begin{array}{c}\text { Control } \\
(\mathrm{n}=8) \\
(\mu \mathrm{mol} / \mathrm{g})\end{array}$} & \multirow{2}{*}{$\begin{array}{c}50 \mathrm{mM} \\
(\mathrm{n}=11) \\
(\mu \mathrm{mol} / \mathrm{g})\end{array}$} & \multirow{2}{*}{$\begin{array}{c}100 \mathrm{mM} \\
(\mathrm{n}=10) \\
(\mu \mathrm{mol} / \mathrm{g})\end{array}$} & \multirow{2}{*}{$\begin{array}{c}200 \mathrm{mM} \\
(\mathrm{n}=9) \\
(\mu \mathrm{mol} / \mathrm{g})\end{array}$} & \multicolumn{6}{|c|}{ Statistical significance } \\
\hline & & & & & $\begin{array}{c}\text { Control } \\
\text { vs. } 50 \mathrm{mM}\end{array}$ & $\begin{array}{c}\text { Control } \\
\text { vs. } 100 \mathrm{mM}\end{array}$ & $\begin{array}{c}\text { Control } \\
\text { vs. } 200 \mathrm{mM}\end{array}$ & $\begin{array}{c}50 \mathrm{mM} \\
\text { vs. } 100 \mathrm{mM}\end{array}$ & $\begin{array}{c}50 \mathrm{mM} \\
\text { vs. } 200 \mathrm{mM}\end{array}$ & $\begin{array}{c}100 \mathrm{mM} \\
\text { vs. } 200 \mathrm{mM}\end{array}$ \\
\hline Thr & $0.483 \pm 0.059$ & $0.528 \pm 0.064$ & $0.927 \pm 0.154$ & $0.937 \pm 0.157$ & NS & $\mathrm{p}<0.001$ & $\mathrm{p}<0.001$ & $\mathrm{p}<0.001$ & $\mathrm{p}<0.001$ & NS \\
\hline Val & $0.089 \pm 0.010$ & $0.081 \pm 0.017$ & $0.098 \pm 0.018$ & $0.095 \pm 0.032$ & NS & NS & NS & NS & NS & NS \\
\hline Met & $0.056 \pm 0.005$ & $0.057 \pm 0.005$ & $0.095 \pm 0.017$ & $0.091 \pm 0.014$ & NS & $p<0.001$ & $\mathrm{p}<0.001$ & $\mathrm{p}<0.001$ & $\mathrm{p}<0.001$ & NS \\
\hline Ile & $0.046 \pm 0.007$ & $0.045 \pm 0.004$ & $0.050 \pm 0.008$ & $0.048 \pm 0.012$ & NS & NS & NS & NS & NS & NS \\
\hline Leu & $0.081 \pm 0.011$ & $0.072 \pm 0.007$ & $0.090 \pm 0.027$ & $0.100 \pm 0.029$ & NS & NS & NS & NS & $\mathrm{p}<0.05$ & NS \\
\hline Tyr & $0.096 \pm 0.015$ & $0.139 \pm 0.020$ & $0.197 \pm 0.043$ & $0.168 \pm 0.050$ & NS & $\mathrm{p}<0.001$ & $p<0.01$ & $\mathrm{p}<0.01$ & NS & NS \\
\hline Phe & $0.085 \pm 0.011$ & $0.132 \pm 0.015$ & $0.173 \pm 0.029$ & $0.206 \pm 0.026$ & $\mathrm{p}<0.001$ & $\mathrm{p}<0.001$ & $\mathrm{p}<0.001$ & $\mathrm{p}<0.001$ & $\mathbf{p}<0.001$ & $\mathrm{p}<0.01$ \\
\hline His & $0.084 \pm 0.010$ & $0.120 \pm 0.014$ & $0.199 \pm 0.035$ & $0.233 \pm 0.020$ & $\mathrm{p}<0.05$ & $p<0.001$ & $\mathrm{p}<0.001$ & $\mathrm{p}<0.001$ & $\mathrm{p}<0.001$ & $\mathrm{p}<0.01$ \\
\hline $\operatorname{Trp}$ & $0.007 \pm 0.002$ & $0.007 \pm 0.003$ & $0.023 \pm 0.011$ & $0.017 \pm 0.006$ & NS & $p<0.001$ & $\mathrm{p}<0.05$ & $p<0.001$ & $p<0.01$ & NS \\
\hline Gln & $\begin{array}{c}4.669 \pm 0.583 \\
(n=11)\end{array}$ & ${ }_{(n=11)}^{10.092 \pm 1.406}$ & $\begin{array}{c}15.136 \pm 2,362 \\
(n=10)\end{array}$ & $\begin{array}{c}19.250 \pm 1.979 \\
(n=13)\end{array}$ & $p<0.001$ & $p<0.001$ & $p<0.001$ & $p<0.001$ & $p<0.001$ & $p<0.001$ \\
\hline
\end{tabular}

Control ; sodium acetate ( $\mathrm{Na} \mathrm{AC)} 200 \mathrm{mM}$,

$50 \mathrm{mM}$; Na Ac $150 \mathrm{mM}+$ ammonium acetate $\left(\mathrm{NH}_{4} \mathrm{Ac}\right) 50 \mathrm{mM}, 100 \mathrm{mM} ; \mathrm{Na} A c 100 \mathrm{mM}+\mathrm{NH}$ Ac $100 \mathrm{mM}, 200 \mathrm{mM} ; \mathrm{NH}$, Ac $200 \mathrm{mM}$

Each solution was continuously infused for 24 hrs at a flow speed of $3.3 \mathrm{~m} l / \mathrm{hr}$ NS ; not significant

下を特變とする血中アミノ酸インバランスと，それに 起因すると考占られる脳内アミノ酸組成の異常 (AAA の増加）が出現することが知られている ${ }^{1,2)}$.さらに AAAのらち Phe 执よびTyrはドパミン, NEといっ た神経伝達物質やオクトパミンフコニルエタノール アミンなどの偽性神経伝達物質の前駆アミノ酸であ ク，またTrpは5-HTの前駆アミノ酸であることから 脳内 AAA の增加と肝性脳症との関連が注目されてき た3,4,8). しかし，このよ5な脳内 AAA の増加が, 単に 血中AAA 濃度の上昇に併行するるのではないといら

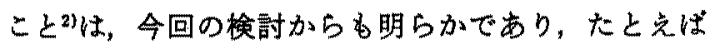
PCAに括いては，血中での Tyr 括よび Phe の增加が 対照の1.3および1.6倍にとどまり，Trpの濃度には差 異が認められなかったのに対し，脳内では Tyr 拈よび Pheはそれぞれ2.2および2.1倍と増加の割合は血中に 比し大きく，Trp あ2.5倍に増加していた (Table 1). 一方, 逆に AIHF においては血中での AAA の堌加の 割合 (Tyr 13.5倍, Phe 6.2, 遊離 $\operatorname{Trp} 5.1$ ) に比し, 脳内での増加はむしろ低くとどまっており（Tyr 6.7 倍, Phe 3.2, Trp 2.1) また BCAA についても同様 にAIHF の血中での増加（Val 1.9倍, Ile 1.8, Leu 2.1)に比し，脳内ではIle には有意な増加が見られず (1.1倍), Val および Leu も1.3倍の増加にとどって いた(Table 2). 従って，この血中之脳内での NAA， とくにAAAの増加度の相違を説明するにあたって

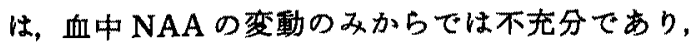

$\mathrm{BBB}$ の透過性そのものの変化をす考慮にいれること が不可欠上思われる。

さて, AAA の脳内移行に際しての BBB の役割につ いては，従来 BBBにおける NAA 相互の競合の面か ら説明が試みられてきた。すなわち, NAA は脳内への 進入に際し，BBBでその輸送担体系を共有し，相互の 競合的阻害を介し移行することから, Munro ら ${ }^{18)}$ は， 競合アミノ酸である BCAAの減少のためTrpの脳内 進入が増加するとし，さらに Pardridge ${ }^{14)}$ は同様な観 点から Michaelis-Menten (M-M)の等式を用いて，血 中 NAA 濃度より脳内進入速度（Vpre）を推定するこ とが可能であるとした。しかし小畐"2は Pardridge ${ }^{14) の ~}$ $\mathrm{M}-\mathrm{M} の$ kinetics (monocomponent) に基づいて対照 群, AIHF, PCA および $\mathrm{NH}_{3}-\mathrm{R} の \mathrm{NAA} の$ V pre (Pardridge) を計算し，実測脳内濃度との相関を検討 した結果, Tyr については PCA と $\mathrm{NH}_{3}$-R で有意の正 相関を示すが, 対照群はこの回㷌直線の士2SDの範囲 をはずれ，AIHF るさらに異なった分布を示すことを 指摘した。ささらに川出8) から遊離 Trpの Vpre (Pardridge) を求め，㬰測した 脳脊髄液中の $\operatorname{Trp}$ 濃度と比較し，Pardridge $\mathrm{e}^{(4)}$ の計算 式の結果以上に Trpの脳内進入がえ進していること を報告した。すなわち，少なくとも M-M の kinetics (monocomponent) に従った BBBに括ける NAA 相 互の競合のみでは，肝不全時の脳内 AAA の増加の説 明は困難であることが判明してきた。 
$38: 202$

肝

一方, BBB における NAA の輸送機棈をのものにも 新たな知見が加党られつつあり，Mansらら Pardridge ${ }^{14)}$ の担体輸送系の他にも単純执散による輸 送系 (nonsat. component) が存在することを明らかに し，著者らの検討でも同様に 2 つの成分の存在するこ とが確認された（Fig. 1)．そこで今回，この正常ラッ

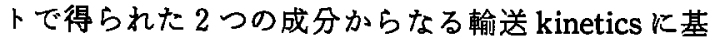
ついて遊離 Trp の Vpre (two components, 以下 2 成 分)を新たに求めたところ, PCA では Trpの脳内実湘 濃度が対照群の2.5倍と増加しているにもかかわらず, Vpre（2 成分）には有意な差異が認められず（Table 1),一方, AIHF に和いては対照群に比し V pre(2 成 分）に有意な増加がみられた（Table 2)，すなわち AIHF では血中 NAA のインバランスをある程度反映

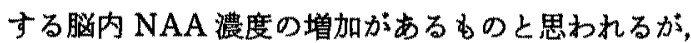
Vpre ( 2 成分)の増加は対照群の1.4倍にとどまり，脳 内実測濃度の2.1倍には及ばなかった(Table 2). 従っ て，2つの成分からなる翰送機構の kinetics をあては めてす，な和血中NAA インバランスの反映としての みでは肝不全時の脳内 NAA 濃度の異常は説明しがた く，やはり肝不全時の BBBに括ける NAA の透過性 そのわのに何らかの異常をきたしていることを，推定 せざるをえない.なお, AIHF の Sham における Vpre （2 成分）が，PCAの Shamより低值を示したのは， 血中遊離 Trp の低值に基づくるのであり，これは10\% ブドウ糖液の腹腔内投与によってるたらされるインス リンの分泌得拉よびTrpのアルブミンとの結合を阻 害するとされる FFAの低下息などが関与している の上推測される。

さて, BUI は bolus injectionにより，血中の濃度に 影響されない血管内から暚内人の標識化合物の移行, すなわち BBB の機能を反映する指標として広く用い られている5,10). そこで,この BUIを指標として, 肝不 全モデルに拈けるTrpの脳内への移行について検討 を試みたところ，-PCA，AIHFいずれる，対照群に比 し有意に高い ${ }^{14} \mathrm{C}$-Trp BUI を示し (Fig. 2)，これら肝 不全モデルではBBBにおけるTrpの透過性そのも のが六進していることが確認された。すなわち，BBB に拈ける NAA の透過性亢進が肝不全モデルにおける 脳内 NAA 代謝異常の発現に重要な役割を担っている 可能性が強く示唆された. AIHFでは，血中NAA イ ンバランスを反映するTrpの脳内進入の増加（Vpre の增加)も諰められることは前述したごとくであるが， 血中での AAA の増加に比べ，脳内での AAA の増加
30 巻 2 号 (1989)

がさしろ低くとどまる点，挌よびこのBBBに括ける NAAの透過性元進の発現機序など関しては, kineticsの面からの検討が必要と思われる。この点に 関し, Mans らちは，同じく BUI を指標として kinetics の面から Trpの脳内移行を検討し, AIHFでは sat. influx のVmax の増加に加劣, nonsat. influx すなわ ち拡散による進入 (Kd) の増加がとくに重要であると 報告している。一方, Cardelli-Cangiano ら6) PCA より単離した脳微小血管 (BMV)を用いて Phe の取り 込みを検討し，その結果，Kdの変化はわずかで，むし ろ Vmax の増加が重要であると報告している.この両 者間には方法の差異もあり，充分な比較は困難である ため，我々もさらにBMVを用いて kineticsの面から 両モデルの比較榆討をすすめている。しかし，少なく

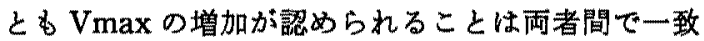
した見解であるといえる。これらの研究に用いられた Trp，Pheなどの NAA は主に system L, すなわち $\mathrm{Na}^{+}$非依存性の exchange transport system を介して 脳内に輸送されるが6,19)，上述した V max の増加が担 体の数の増加によるるか, exchange transport の元 進によるものか，あるいはその両者の因子が関与して いるのかは，いまだ十分に解明されていない，たたし， 高 $\mathrm{NH}_{3}$ 血症と exchange transport の関俰に着目した James ら7の仮説，すなわち，高 $\mathrm{NH}_{3}$ 血症時，脳内で $\mathrm{NH}_{3}$ 解毒が穴進するため $\mathrm{Gln}$ の産生が高まり, 脳より 血中への Gln の放出が増加し, その結果, BBB におい て Gln と共通の輸送担体系を有するNAAの脳内進 入が増加するとの仮説は注目に值する、さらに, James らクは脳内より血中への NAAの流出もGln との競合 によって抑えられるため，先に述べた NAAの脳内進 入の六進とあいまって NAA の実測脳内濃度が增加す ると推定して扣り，NAAの脳内輸送機構に及ぼす $\mathrm{NH}_{3}$ の影響の重要性を指摘している.

今回の検討でも，PCA および AIHF においては，高 $\mathrm{NH}_{3}$ 血症とともに，脳内での著明な Gln の増加が認め られ(Fig. 3), さらに, 脳内 Gln 濃度と ${ }^{14} \mathrm{C}-T r p の$ BUI との間に有意の正の相関が認められた（Fig. 4）こと は,この James ら゙の仮説に矛盾しない所見と考えら れる. しかし, James ら゙の用いたモデルは90分間に 3 回， $\mathrm{NH}_{3}$ を腹腔内投与したものであり，少なくとも PCAのよ 5 な慢性の高 $\mathrm{NH}_{3}$ 血症を呈する病態での $\mathrm{NH}_{3}$ の影響を検討するもデルとしては充分とは言い 難い.

そこで，高 $\mathrm{NH}_{3}$ 血淀自体と脳内 GIn 括よびAAA 濃 
度との関連をより明確にするため, $\mathrm{NH}_{3}$ の24時間持続 投与によって $\mathrm{NH}_{8}-\mathrm{R}$ を作製して検討したところ，こ のようなモデルにおいてるAAAの增加を特徵とする 脳内 NAAのインバランスが観察された (Table 3). 我々の用いた $\mathrm{NH}_{3}-\mathrm{R}$ は, 小畠党によればラットの体重 (180 220g)および輸液速度 $(4 \mathrm{~m} l / \mathrm{hr})$ に若干の差異 はあるものの, $200 \mathrm{mM}$ 群で血浆中の $\mathrm{NH}_{3}$ の增加（平 均 $550 \mu \mathrm{g} / \mathrm{d} l$ ) と総蛋白濃度の軽度低下を認める以外， 肝機能上, 総ビリルビン, LDH, GPT には正常群との 間に有意差は認められず, $\mathrm{NH}_{3}$ そのものの代謝毒性を 検討する上で極めて有用なモデルであると考えられ る.さららに血中 $\mathrm{NH}_{3}$ 濃度は今回測定していないが，脳 内 $\mathrm{G} \ln$ 濃度から比較した場合, $50 \mathrm{mM}$ 群の 10.1 (平均, $\mu \mathrm{g} / \mathrm{d} l), 100 \mathrm{mM}$ 群の15.1括よび200mM 群の19.3は PCA の11.9招よびAIHF の15.2に注淩匹敵する值で あり，PCA 括よびAIHFに打ける $\mathrm{NH}_{3}$ の影響をよく 反映しているものと考えられる (Table 3, Fig. 3).

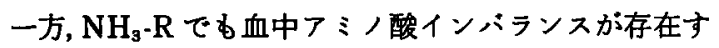
ることも知られている2,9 が，この血中アミ，酸組成の 変化のみでは脳内での NAA の变化を説明しえないこ とは前述した通りである。

実際，この $\mathrm{NH}_{3}-\mathrm{R}$ におけるる ${ }^{14} \mathrm{C}-\operatorname{Trp} の \mathrm{BUI}$ を検討 したところ，50mM，100mM および $200 \mathrm{mM}$ 群とも対 照群に比し，有意に增加しており，高 $\mathrm{NH}_{3}$ 血症そのも のによっても，BBBにおけるTrpの脳内移行の元進 が招来されることが明らかとなった(Fig. 5). また， ${ }^{14}$ C-Ileの BUIについても同様に有意な増加が示され (Fig. 6), AAAのみならず, BCAA の取り込み增加 しているすのと考えられだ.

さらに,こうした BBBにおけるNAAの透過性え 進が， $\mathrm{NH}_{3}$ の BBB に対する直接の作用に基つくのか 否かを検討するため, inj. sol. に $\mathrm{NH}_{3}$ を加克，同様に C-Trpの BUI を検討してみたが, 対照群との間に有意 な差異は認められず(Fig. 7)， $\mathrm{NH}_{3}-\mathrm{R}$ に打ける BBB の透過性六進は $\mathrm{NH}_{3}$ のBBに対する直接の作用で はなく, 高 $\mathrm{NH}_{3}$ 血症を誘因として二次的に惹起される すのであると推察される。

脳内の過剩な $\mathrm{NH}_{3}$ の解毒は主に $\alpha$ ケトダルタル酸 $\rightarrow \mathrm{Glu} \rightarrow \mathrm{Gln}$ の経路でおこなわれるが, この結果, 脳 内の Gln 濃度は著明に増加する (Table 3). この脳内 Gln 濃度の増加之脳内 $\mathrm{AAA}$ 濃度の和 ( $\mathrm{Tyr}+\mathrm{Phe}+$ Trp）との間には強い正相関がみられ (Fig. 8), さら K, $\mathrm{NH}_{\mathrm{a}}-\mathrm{R}$ に扣いても，脳内 Gln 濃度と ${ }^{14} \mathrm{C}$-Trp BUI との間に正の相関がみられた（Fig. 9）ことは，脳内
Gln と NAA が共通の exchange transport system を 介して輸送される可能性を強く支持する所見と考えら れる. また, $\mathrm{NH}_{3}-\mathrm{R} に \mathrm{Gln}$ synthetase inhibitor であ る L-methionine-dl-sulfoximineを投与すると，脳内 Gln 濃度とともに脳内 AAA 濃度の増加も抑制される との Jonung ら 201の報告は，この成績をさらに支持す るものであろら。

以上ょり，肝不全時の BBBにおけるNAAの透過 性の六進に高 $\mathrm{NH}_{3}$ 血症が密接な関連を持っているこ とを明らかにし得た。さらに， $\mathrm{NH}_{3}$ 解毒のため脳内に 増加したGlnが NAAの脳内蓄積に重要な役割を 担っている可能性が示唆されたが,この点に関しては, いまだ直接的な証明はなされておらず，今後さらに検 討していく必要があるう。

\section{結 語}

PCA 拉よび AIHFに执いては，対照群に比し， ${ }^{14} \mathrm{C}$ $\operatorname{Trp}$ の BUIは有意に増加しており, 肝不全時, とくに 肝性脳症時の脳内 NAA 代謝異常の発現にBBB けるNAAの透過性六進が重要な役割を担っているす

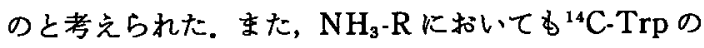
BUI は有意に增加しており，このBBBにおける透過 性元進の発現は，高 $\mathrm{NH}_{3}$ 血症自体と密接な関連のある ことを明らかにした，さらに，PCA，AIHFおよび $\mathrm{NH}_{3}-\mathrm{R}$ に打いて脳内 $\mathrm{G} \ln$ 濃度と ${ }^{14} \mathrm{C}$-Trp の BUI が有 意な正相関を示したことは，肝不全時の BBBに拈け る NAA の透過性六進が，脳内で $\mathrm{NH}_{3}$ 解毒のため増加 した Gln と NAA との exchange transport の六進に すとづいて起こるとする Jamesらりの仮説に矛盾しな い結果であっだ。

稿を終えるにあたり，御教示をいただきました高橋善弥 太前教授，川出靖彦ならびに小皇正夫博士に深謝いたしま 寸.

本論文の要旨は第23回 (昭和56年10月，米子）おょび第24 回(昭和57年10月, 山形) 日本消化器病学会秋季大会に批い て発表した。

\section{文献}

1) Fischer JE, Rosen HM, Ebeid AM, et al: The effect of normalization of plasma amino acids on hepatic encephalopathy in man. Surgery 80 : 77-91, 1976

2）小皇正夫：各種肝不全モデルに括ける血策つミ， 酸バターンからみた腃内てミノ酸の動蟹に関する 研究。岐鼻医紀，29：870-908，1981 
3）斎藤公志郎：肝性脳症飞扣ける䏚内モノフミン代 謝暴常に関する研究 (I) 一脳内カテコールマミン

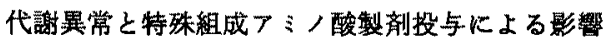
一. 岐阜医紀 $29: 1310-1324 ， 1981$

4）橋本 修：肝性脳症に扰ける䏚内セ口トニン代謝 異常に関する研究 (II) 一特殊組成了ミノ酸混液

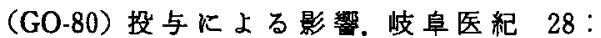
613-628, 1980

5) Mans AM, Biebuyck JF, Saunders SJ, et al : Tryptophan transport across the blood-brain barrier during acute hepatic failure. J Neurochem 33 : 409-418, 1979

6) Cardelli-Cangiano $P$, Cangiano $C$, James JH, et al: Uptake of amino acids by brain microvessels isolated from rats after portacaval anastomosis. J Neurochem $36: 627-632,1981$

7) James JH, Ziparo V, Jeppson B, et al: Hyperammonia, plasma aminoacid imblance, and blood-brain aminoacid transport: a unified theroy of portal-systemic encephalopathy. Lancet : $772-775,1979$

8）川出靖彦：トリプトフォンと肝性脳症発現機序と の関係汇関する研究。岐阜医紀 $29: 748-785$, 1981

9）林 真功：肝硬变症における血中分枝鎖 の低下の発生機序に関する研究 (II)ーフンモニフ 投与の血中フミノ酸濃度に及ぼす影響一，岐阜医 紀 $29: 630-641,1981$

10) Oldendorf WH : Uptake of radiolabeled essential amino acids by brain following arterial injection. PSEBM 136 : 385-386, 1971

11) Eklöf $B$, Holmin $T$, Johansson $H$, et al : Cerebral blood flow and cerebral metabolic rate for oxygen in rats with portacaval anastomosis. Acta Physiol Scand 90 : 337-344, 1974
12) Daniel PM, Platt OE, Wilson PA: The transport of L-leucine into the brain of rat in vivo: saturable and nonsaturable components of influx. Proc. R. Soc. Lond B196 : 333-346, 1977

13) Eccleston EG : A method for the estimation of free and total acid-soluble plasma tryptophan using an ultrafiltration technique. Clin Chim Acta 48 : 269-272, 1973

14) Pardridge WM: Kinetics of compentitive inhibition of neutral amino acid transport across the blood-brain barrier. J Neurochem 28: 103 $-108,1977$

15) Lund $P$ : Determination with glutaminase and glutamate dehydrogenase. In: Methods of Enzymatic Analysis, Edited by Bergmeyer HU, Academic Press, New York, 1974, p1719-1722

16) Bernt E, Bergmeyer HU: L-glutamate-UVassay with glutamate dehydrogenase and NAD. In : Methods of Enzymatic Analysis, Edited by Bergmeyer HU, Academic Press, New York, 1974, p1704-1708

17) Bailey BJR: Tables of the Bonferroni t statistic. J Am Stat Asoc 72 : 469-478, 1977

18) Munro HM, Fernstrom JD, Wurtman RJ : Insulin, plasma aminoacid imbalance, and hepatic coma. Lancet : 722-724, 1975

19) Christensen $H N$, Handlogten $M E$ : Interaction between parallel transport systems examined with tryptophan and related amino acids. J Neural Transmission Suppl. 15: 1-13, 1979

20) Jonung $T$, Rigotti $P$, Jeppsson $B$, et al : Methionine sulfoximine prevents the accumulation of large neurtral amino acids in brain of hyperammonemic rats. J Surg Res 36 : 349-353, 1984 


\title{
Tryptophan transport across blood-brain barrier in rats with hepatic failure
}

\author{
Toshiyuki Nakamura, Koshiro SaITo, Hisataka MoRIwaKI, \\ Osamu Hashimoto and Yasutoshi Muto*
}

A study was conducted to investigate changes of tryptophan (Trp) transport across blood-brain barrier in hepatic encephalopathy. Hepatic failure was induced in rats by either portacaval anastomosis (PCA), acute ischemic hepatic failure (AIHF) or continuous infusion of ammonium acetate $\left(\mathrm{NH}_{3}\right)$. The permeability of blood-brain barrier to Trp was examined employing the method of brain uptake index (BUI). The following results were obtained:

1) $\mathrm{PCA}$ as well as AIHF rats showed significantly higher BUI of ${ }^{14} \mathrm{C}$-Trp as compared with control.

2) In $\mathrm{NH}_{3}$-infused rats, significant elevation in BUIs of ${ }^{14} \mathrm{C}$-Trp and of ${ }^{14} \mathrm{C}$-isoleucine was observed when compared to control.

3) In all of three hepatic failure models, a significant positive correlation was demonstrated between BUI of ${ }^{14} \mathrm{C}$-Trp and glutamine levels in the brain, which is elevated presumably due to the enhanced detoxication of $\mathrm{NH}_{3}$ in the brain.

In conclusion, the increased permeability of blood-brain barrier in hepatic failure is clearly demonstrated and is further suggested to have been induced by elevated cerebral level of glutamine. In addition, it is also conceivable that the increased permeability of blood-brain barrier may contribute to the elevation in cerebral concentration of neutral amino acids such as Trp.

* First Department of Internal Medicine, Gifu University School of Medicine (Gifu) 